\title{
Improved Purification Procedure and RNA Segments of Rice Ragged Stunt Virus*
}

\author{
Toshihiro Omura**, Yuzo Minobe**, Ikuo Kimura**, Hiroyuki Hibino***, \\ Tsuneo Tsuchizaki** and Yasuo SaIto** \\ 大村敏博 $* *$ 美濃部侑三**・木村郁夫**・日比野啓行 $* * * \cdot$ 土崎常男 $* * \cdot$ 斎藤康夫 $* *$ : \\ イネ・ラギッド・スタント・ウイルスの純化法の改良と分節 RNA 数*
}

\begin{abstract}
Purification of rice ragged stunt virus (RRSV) was improved by using Triton $\mathrm{X}-100$ as a detergent, adding $\mathrm{MgCl}_{2}$ in suspension buffers and using histidine buffer in the latter step of the procedure. The purified virus particles were about $55 \mathrm{~nm}$ in diameter and highly infectious to rice seedlings, inoculated via vector insects (Nilaparvata lugens). Ten double stranded ribonucleic acid (RNA) segments with approximately equimolar amounts, including newly found two segments, were found in purified RRSV. A total molecular weight of the RNA was $22.91 \times 10^{6}$ based on the standards doveloped by Galinski et al. ${ }^{4}$
\end{abstract}

(Received May 30, 1983)

Key Words : RRSV, RNA segments, ds-RNA. purification, plant reovirus.

\section{Introduction}

Rice ragged stunt virus (RRSV) which is prevalent in South and Southeast Asia ${ }^{9,11}$ was recently recognized as a possible member of the group of Plant reovirus ${ }^{8,19)}$. Purificaiton of RRSV has not been successful presumably due to the low virus concentration in infected rice plants and/or labile nature of the particles ${ }^{7,12)}$. The virus was reported to contain double stranded ribonucleic acid (ds-RNA) separated into 8 approximately equimolar bands with a total molecular weight of $11.63 \times 10^{6}$ using RNA purified directly from the enation of virus-infected plants ${ }^{11}$. A plant reovirus is classified into two subgroups: the Phytoreovirus (plant reovirus subgroup 1) with 12 separated genomes and the Fijivirus (plant reovirus subgroup 2) with 10 separated genomes as subgroups ${ }^{13)}$. The number of the separated genomes of RRSV seems to show that the virus might be distinct from the two plant reovirus subgroups. However, most characteristics of RRSV such as symptoms of infected plants, vector species, transmission mode by vectors ${ }^{9,11)}$, particle morphology ${ }^{8,19)}$ and nature of double stranded genome RNA except for the number of the genome segments ${ }^{1)}$ suggest that the virus belongs to the Fijivirus subgroup ${ }^{14)}$. We improved the purification procedure

* Some of the investigations reported here were part of a collaborative research project titled "Studies on Rice and Legumes Virus Diseases in the Tropics" supported by the Tropical Agriculture Research Center, Japan.

** Institute for Plant Virus Research, Tsukuba Science City, Yatabe, Ibaraki 305, Japan 農林 水産省植物ウイルス研究所

*** International Rice Research Institute, P. O. Box 933, Manila, Philippines 国際イネ研究所 
of RRSV, and analyzed RNA genome segments of the purified virus by electrophoresis.

\section{Meterials and Methods}

Virus, insects and plants. The virus was maintained and propagated in rice plants (cultivar Taichung Native 1) by transmitting the virus using viruliferous Nilaparvata lugens as reported by Hibino and Kimura?).

Cytoplasmic polyhedrosis virus (CPV) was kindly supplied by Dr. S. Miyajima.

Virus purification. The method applied for the purification of rice gall dwarf virus $^{16)}$ was modified for RRSV. All the operations were performed either in an ice bath or at $4 \mathrm{C}$. Fresh leaves or roots about 40 days after inoculation were ground with a meat chopper in two volumes $(\mathrm{w} / \mathrm{v})$ of $0.1 \mathrm{M}$ sodium phosphate buffer, $\mathrm{pH} 7.0$ containing $0.01 \mathrm{M} \mathrm{MgCl} 2$ ( $\mathrm{PB}-\mathrm{Mg})\left(\mathrm{MgCl}_{2}\right.$ was added immediately before use). The homogenate was passed through a layer of finely woven cotton cloth, added with carbon tetrachloride $\left(\mathrm{CCl}_{4}\right)$ to a final concentration of $20 \%$, and blended in a Warling Blendor for $2 \mathrm{~min}$. After centrifugation for $15 \mathrm{~min}$ at $3,000 \times \mathrm{g}$, the supernatant fluid was added with polyethylene glycol 6,000 (PEG), $\mathrm{NaCl}$ and Triton $\mathrm{X}-100$ to a final concentration of $6 \%(\mathrm{w} / \mathrm{v}), 0.3 \mathrm{M}$ and $1 \%(\mathrm{w} / \mathrm{v})$, respectively. The mixture was stirred for $40 \mathrm{~min}$, and then centrifuged for $15 \mathrm{~min}$ at $6,000 \times \mathrm{g}$. The pellet was resuspended in $0.1 \mathrm{M}$ histidine buffer containing $0.01 \mathrm{M} \mathrm{MgCl} 2$ ( $\mathrm{pH} 7.0$ ) (His- $\mathrm{Mg}$ ), incubated for $30 \mathrm{~min}$ and centrifuged for $15 \mathrm{~min}$ at $3,000 \times \mathrm{g}$. The supernatant was treated with $\mathrm{CCl}_{4}(10 \%)$, and then centrifuged for $40 \mathrm{~min}$ at $96,000 \times \mathrm{g}$. The pellet was resuspended in His $-\mathrm{Mg}$, incubated for $30 \mathrm{~min}$, and centrifuged for $15 \mathrm{~min}$ at 3,000 $\times g$. The supernatant fluid was layered on a $10-40 \%(\mathrm{w} / \mathrm{v})$ linear sucrose gradient in His $-\mathrm{Mg}$ and centrifuged for $1 \mathrm{hr}$ at $87,000 \times g$ in a Hitachi RPS-27 rotor. The zone containing virus particles was recovered with an ISCO model UA 2 scanner, layered on a $40-60 \%(\mathrm{w} / \mathrm{v})$ linear sucrose gradient in His-Mg, and centrifuged for $15 \mathrm{hr}$ at $62,000 \times g$ in a Hitachi RPS-27 rotor. The gradient was fractionated by the scanner, and viruses in the fraction were concentrated by centrifugation for $2 \mathrm{hr}$ at $96,000 \times g$. The final pellet was resuspended in His- $\mathrm{Mg}$. Some steps in the purification were monitored by electron microscopy.

CPV was purified by a slight modification of the method described by Miyajima et al. ${ }^{15)}$ The extracting buffer was $0.01 \mathrm{M}$ Tris, containing $0.15 \mathrm{M} \mathrm{NaCl}, \mathrm{pH} 7.0$, and glycerol gradient was used. The final pellet was suspended in $\mathrm{His}-\mathrm{Mg}$.

Electron microscopy. Viral preparations were stained in $2 \%$ aqueous uranyl acetate (UA) and were examined with a Hitachi $\mathrm{H}-500$ electron microscope.

Virus injection. Purified preparations of RRSV $\left(A_{260}=1.0\right)$ were injected into the abdomen of third- to fourth-instar nymphs of $N$. lugens in the same manner as described before ${ }^{16)}$.

Extraction of RNA. The phenol-sodium dodecyl sulfate (SDS) procedure $^{2)}$ was employed to extract RNA from purified virus. Alternatively, RNA was released by adding $1 \%$ SDS and $0.01 \%$ ethylenediaminetetraacetic acid (EDTA) to purified virus preparations, and was directly used for electrophoresis ${ }^{18)}$.

Electrophoresis. Slab gels consisting of $7.5 \%(\mathrm{w} / \mathrm{v})$ acrylamide and $0.2 \%$ $(\mathrm{w} / \mathrm{v})$ bisacrylamide were prepared by the method of $\mathrm{Laemmli}^{10)}$, as applied by 
Ramig et al. ${ }^{17)}$ for reovirus genome RNAs. Electrophoresis was performed at room temperature for 6 or $12 \mathrm{hr}$ at $30 \mathrm{~mA} / \mathrm{gel}$ in $0.025 \mathrm{M}$ Tris- $\mathrm{HCl}, \mathrm{pH} 8.3$ containing $0.192 \mathrm{M}$ glycine and $0.1 \%$ SDS (Tris-glycine). The gels were washed in dist. water, and RNA bands were traced using the Shimazu chromatoscanner CS-910 and were then stained with ethidium bromide in dist. water $(1 \mu \mathrm{g} / \mathrm{ml})$. RNA bands were visualized under U. V. light and were photographed onto the Polaroid film type 665 .

\section{Results}

\section{Virus purification}

Yicld of virus was higher in roots than in leaves of infected plants. Addition of $\mathrm{MgCl}_{2}$ to the buffer solution stabilized virus particles and reduced particle disintegration during purification as compared to the case without using the chemical. Histidine buffer which was used at the latter step of purification was also useful for preservation of particle structure. The use of Triton $\mathrm{X}-100$ was effective for removing the host material from virus fraction. Without the detergent treatment, the purified preparation still contained membranous host materials.

\section{Electron microscopy}

Particles about $55 \mathrm{~nm}$ in diameter with spikelike projections were observed in the purified preparations (Fig. 1). Outer capsid shells of particles were not found in purified

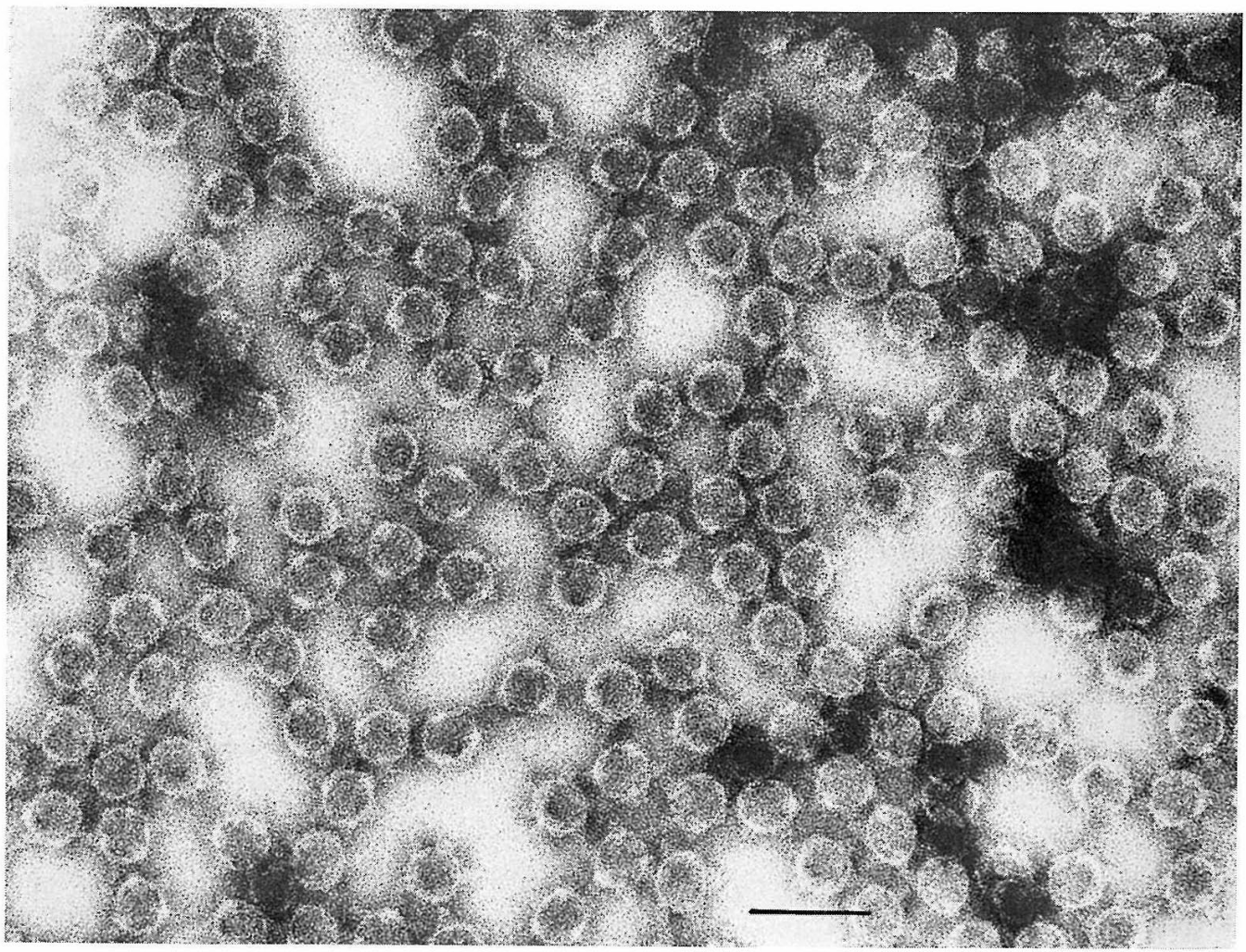

Fig. 1. Purified RRSV stained with $2 \%$ UA. Bar represents $100 \mathrm{~nm}$. 
virions and their morphology was quite similar to that of $\mathrm{CPV}^{5)}$.

\section{Infectivity assay}

As shown in Table 1, 71-81\% of the insects given inoculation access feeding on test rice seedlings induced typical symptoms of rice ragged stunt disease in plants.

Table 1. Infectivity of purified RRSV

\begin{tabular}{ccccc}
\hline \hline & \multicolumn{3}{c}{ Number of insects } & \\
\cline { 2 - 4 } Exp. no. & injected & $\begin{array}{c}\text { survived } \\
12 \text { days }\end{array}$ & $\begin{array}{c}\text { transmitted } \\
\text { virus } \\
\text { transmission }\end{array}$ \\
\hline I & 100 & 21 & 15 & 71 \\
II & 100 & 52 & 42 & 81 \\
Control $^{\text {a) }}$ & 100 & 46 & 0 & 0 \\
\hline
\end{tabular}

a) Vuffer-injected control.

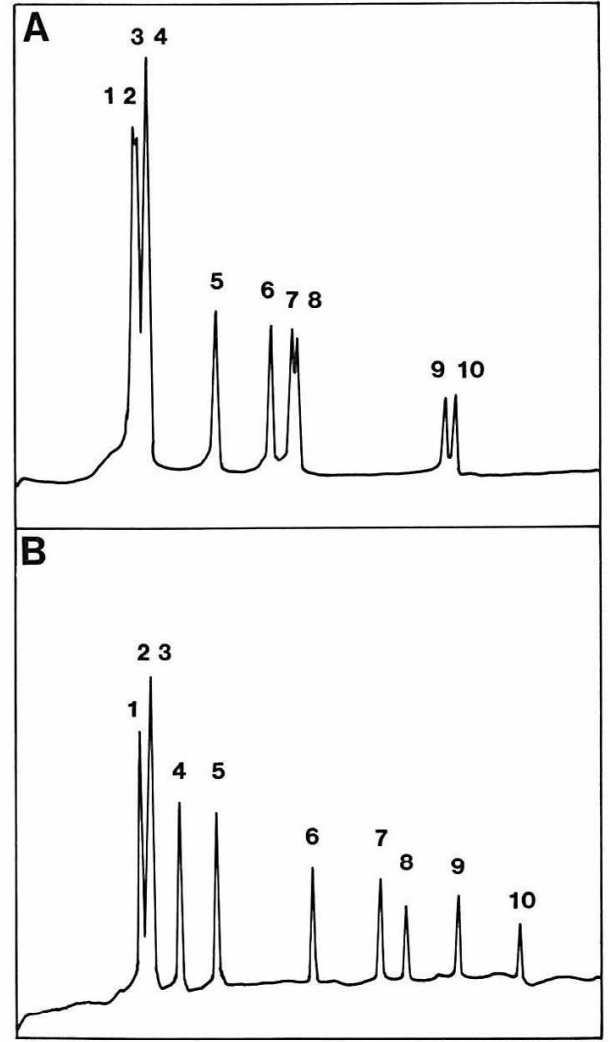

Fig. 2. Densitometer tracings of RNA segments of RRSV (A) and $\mathrm{CPV}$ (B), electrophoresed in a $7.5 \%$ slab gel $(140 \times 100 \times 1.5$ $\mathrm{mm}$ ) for $6 \mathrm{hr}$ at $30 \mathrm{~mA}$.

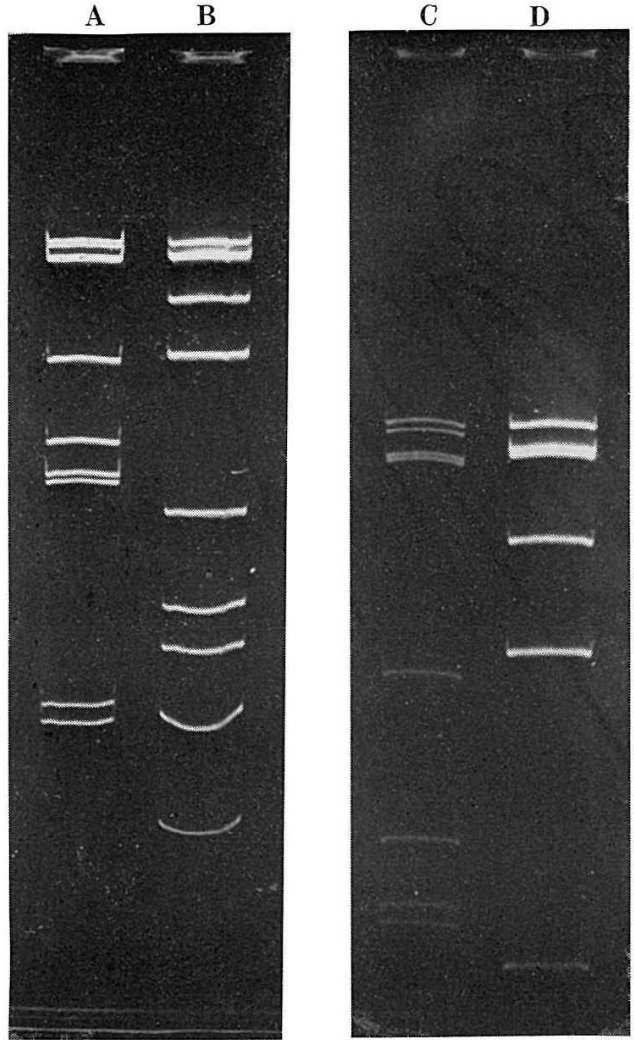

Fig. 3. Photographs of gels in which the RNA segments of RRSV and CPV genomes were separated by electrophoresis in a $7.5 \%$ slab gel. The electrophoresis was pcrformed for $6 \mathrm{hr}(\mathrm{A}, \mathrm{B})$ and 12 $\mathrm{hr}$ (C, D) at $30 \mathrm{~mA}$, and the gels were stained with ethidium bromide. Migration was from top to bottom. A and C, RRSV RNA ; B and D, CPV RNA. Low molecular weight segments moved away from the gel in $\mathrm{C}$ and $\mathrm{D}$. 
Table 2. Molecular weight of RRSV RNA segments compared with those of CPV

\begin{tabular}{cccccc}
\hline \hline Segment no. & RRSV $\left(\times 10^{6}\right)$ & $\left.\mathrm{CPV}^{\mathrm{a}}\right)\left(\times 10^{6}\right)$ & $\mathrm{RRSV}\left(\times 10^{6}\right)$ & $\left.\mathrm{CPV}^{\mathrm{b}}\right)\left(\times 10^{6}\right)$ & $\mathrm{RRSV}^{\mathrm{c}}\left(\times 10^{6}\right)$ \\
\hline 1 & 3.64 & 3.61 & 2.57 & 2.55 & 2.53 \\
2 & 3.55 & 3.28 & 2.49 & 2.42 & \\
3 & 3.40 & 3.28 & 2.42 & 2.32 & 2.48 \\
4 & 3.38 & 2.76 & 2.40 & 2.03 & \\
5 & 2.38 & 2.45 & 1.73 & 1.82 & 1.79 \\
6 & 1.76 & 1.38 & 1.30 & 1.12 & 1.38 \\
7 & 1.55 & 1.11 & 1.17 & 0.84 & 1.23 \\
8 & 1.52 & 0.96 & 1.14 & 0.62 & 1.20 \\
9 & 0.88 & 0.83 & 0.54 & 0.52 & 0.52 \\
10 & 0.85 & 0.66 & 0.50 & 0.35 & 0.50 \\
& 22.91 & 20.32 & 16.24 & 14.59 & 11.63 \\
\hline
\end{tabular}

a) Galinski et al. (1982)4), b) Fujii-Kawata et al. $(1970)^{32}$, c) Boccardo and Milne (1980) ${ }^{13}$.

\section{Electrophoresis of RNA}

RRSV genome could be resolved in 9 distinct segments in $7.5 \%$ gels using the system of Laemmli ${ }^{10)}$ (Figs. 2A, 3A). The third band was thick and broad, and expected to contain about twice as much molecules as the others judging from the peak height of the densitometric tracing (Figs. $2 \mathrm{~A}, 3 \mathrm{~A}$ ). As shown in Fig. $3 \mathrm{C}$, the band was separated into two segments by prolonged electrophoresis (12 hr) in the same system. No difference in distribution and number of RNA segments was found between RNAs extracted with SDS-phenol and those obtained by treating the virus with SDS-EDTA. The molecular weight of RRSV RNA segments was estimated by comparing their mobility with that of CPV (Table 2). Recently, Galinski et al. ${ }^{4)}$ reported the corrected molecular weight estimate for CPV. In the present study, molecular weights were compared using native RNAs. The total molecular weight of RRSV RNA was 22.91 $\times 10^{6}$ with a segmental range of $0.85-3.64 \times 10^{6}$ when estimated in using the standards developed by Galinski et al. ${ }^{4)}$ Molecular weight of nucleic acid was also estimated using standards reported by Fujii-Kawata $e t a l .{ }^{3)}$ for the comparison with previously published molecular weight estimates of ds-RNA segments (Table 2). The data of RRSV RNA presented by Boccardo and Milne ${ }^{1)}$ are also shown in Table 2.

\section{Discussion}

Insects injected with the purified $55 \mathrm{~nm}$ particles were able to transmit the disease, suggesting that the $55 \mathrm{~nm}$ particle is the causal agent of the disease. Contaminant host material was not observed in the purified preparation (Fig. 1) and the purification was markedly improved as compared to those reported before? ${ }^{72}$. Virions in purified preparation were lack of outer capsids. Perhaps they would be removed out during purification, for outer layer was observed in dipped preparations of infected plants stained with $\mathrm{UA}^{6)}$, and in thin sections of both infected plants and insect vectors ${ }^{8}$. In the purified particles, the stain penetrated inside in most particles (Fig. 1). The permeability of the inner cores might be altered presumably due to the long purification 
procedures.

Results of the present study showed that RNAs of RRSV could be separated into 10 segments confirming that the virus belongs to the Fijivirus subgroup. The use of $7.5 \%$ gel with Tris-glycine buffer system employed in this experiment enabled the separation of slow migrating bands. Distribution of RNA segments of RRSV shown in Table 2 is similar to that reported by Boccardo and Milne ${ }^{1)}$, except for the two new segments found in this experiment (Fig. 3). Though there is a possibility that RRSV may not belong to the Fijivirus subgroup due to the novel distribution of the molecular weight as already suggested by Boccardo and Milne ${ }^{1)}$, it is considered that RRSV can be tentatively included in Fijivirus subgroup.

\section{Acknowledgments}

The authors are grateful to Dr. S. Miyajima, Aichi-ken Agricultural Research Center, for supplying CPV and to Dr. T. Hibi, Institute for Plant Virus Research, for his fruitful suggestions.

\section{Literature cited}

1. Boccardo, G. and Milne, R. G. (1980). Intervirology 14: 57-60.

2. Bockstahler, L.E. and Kaesberg, P. (1965). J. Mol. Biol. 13: 127-137.

3. Fujii-Kawata, I., Miura, K-I. and Fuke, M. (1970). Ibid. 51: 247-253.

4. Galinski, M. S., Chow, K-C., Rohrmann, G. F., Pearson, G. D. and Beaudreau, G. S. (1982). Virology 123: 328-335.

5. Hatta, T. and Francki, R. I. B. (1982). Intervirology 18: 203-208.

6. Hibino, H. (1979). Rev. Plant Protec. Res. 12: 98-110.

7. Hibino, H. and Kimura, I. (1982). Phytopathology 72: 656-659.

8. Hibino, H., Saleh, N. and Roechan, M. (1979). Ann. Phytopath. Soc. Japan 45: 228-239.

9. Hibino, H., Roechan, M., Sudarisman, S. and Tantera, D. H. (1977). Contrib. Centr. Res. Inst. Agric. Bogor. No. 35: 1-15.

10. Laemmli, U.K. (1970). Nature, London 227: 680-685.

11. Ling, K. C., Tiongco, E. R. and Auguiero, V. M. (1978). Plant Dis. Rep. 62: 701-705.

12. Luisoni, E., Milne, R. G. and Roggero, P. (1982). Plant Dis. 66: 929-932.

13. Matthews, R.E. F. (1982). Intervirology $17: 85-88$.

14. Milne, R. G. and Lovisolo, O. (1977). Adv. Virus Res. 21 : 267-341.

15. Miyajima, S., Kimura, I. and Kawase, S. (1969). Invertebr. Pathol. 13: 296-302.

16. Omura, T., Morinaka, T., Inoue, H. and Saito, Y. (1982). Phytopathology 72: 1246-1249.

17. Ramig. R. F., Cross, R. K. and Fields, B. N. (1977). J. Virol. 23: 726-733.

18. Reddy, D. V. R. and Black, L. M. (1973). Virology 54 : 557-562.

19. Shikata, E., Senboku, T., Kamjaipai, K., Chou, T. G., Tiongco, E. R. and Ling, K. C. (1979). Ann. Phytopath. Soc. Japan 45: 436-443.

和 文摘 要

$$
\text { イネ・ラギッド・スタント・ウイルスの純化法の改良と分節 RNA 数 }
$$

大村敏博・美濃部侑三・禾村郁夫 $・$ 日比野啓行 $・$ 土崎常男・斎藤康夫

イネ・ラギッド・スタント・ウイルスの純化法を Triton $\mathrm{X}-100$ の使用, 緩衝液に $\mathrm{MgCl}_{2}$ を添加するこ と招よび純化の後半にヒスチジン緩衝液を用いることによって改良した。径約 $55 \mathrm{~nm}$ の純化粒子を注射した トビイロウンカはイネに本病特有の病気を伝搬したことから, 本粒子がイネ・ラギッド・スタント病の病原 ウイルスであることを確認した。純化ウイルス粒子から得た 2 本鎖 RNA は10本に分節していた。Galinski ら ${ }^{4)}$ の報告に基づいて計算した核酸の総分子量は $22.91 \times 10^{6}$ ダルトンであった。 